\title{
Let me Fly Abroad: Student Migrations in the Context of Nepal
}

\author{
Min Kumar Tamang ${ }^{1} \&$ Milan Shrestha*2
}

* Corresponding author

E-mail: milan.776781@gse.tu.edu.np

1. Kathmandu University School of

Education, Lalitpur, Nepal

2. Graduate School of Education, Tribhuvan University, Kirtipur, Nepal

\section{Article Info}

Received: October 5, 2020

Revised: December 8, 2020

Accepted: April 14, 2021

\section{L0.46303/repam.2021.1}

\section{How to cite}

Tamang, M. K. \& Shrestha, M. (2021). Let me Fly Abroad: Student Migrations in the Context of Nepal. Research in Educational Policy and Management, 3(1), 1-18. https://doi.org/10.46303/repam.2021.1

\section{Copyright license}

This is an Open Access article distributed under the terms of the Creative Commons Attribution 4.0 International license (CC BY 4.0).

\begin{abstract}
Student migration has been increasing over recent years in Nepal. The increasing numbers of students leave the country to the developed countries for their higher education with the hope of getting practical skills and knowledge and other valuable experiences to enhance their future carrier. This paper intends to explore the motivation and excitements among international students while flying abroad to pursue their higher education from the developed countries. In doing so, narrative inquiry was adopted as research methodology with the aim of exploring their stories of mobility. Using purposive sampling, three participants were selected from International English Language Testing System (IELTS) preparatory class for the study, while data was collected through in-depth interview using open ended questions. The collected data was further transcribed, coded, categorized and thematized in the process of meaning making. The study revealed that students who have moved abroad have their own stories of motivation and excitement. Their stories of motivation, as the study revealed, were linked to their expectation of handsome earning and pursuing a foreign degree. Moreover, this paper also highlights the motivation of prospective students and their desire to fly abroad for their academic journey.

\section{KEYWORDS}

Abroad study, excitement, motivation, student migration. 


\section{INTRODUCTION}

The motivation to explore the stories of migrant students started with my own reflection into the year 2009 when, as a young desperate student, I moved to one of the international universities in the United Kingdom (UK). I completed my master-level study in the discipline of international management from the University of Teesside, UK, garnering valuable experiences and confidence to start up my own business in my homeland Nepal. As a young student migrant, I spent 6 years in the UK and returned to Nepal in 2014 thinking that I would lead an educational consultancy and provide counseling to the young students who aspire to go abroad. Although I had multiple options for the possible profession such a teacher, banker, entrepreneur, and broker I was determined to fulfill my desire. As a result, immediately after my return, I was able to outset my own educational consultancy company in Kathmandu, the capital of Nepal. I was scared about my business in the initial stage since it was tough to compete in the market. Nevertheless, the flow of the students went more.

Let me reflect on my situation abroad. I have observed many of my friends who had not got a job even after they completed their postgraduate education in Nepal. My case was also similar. Though I had a master's degree in English literature from Tribhuvan University (TU), I was unable to support my family financially. I failed to access any job, as a result, my family continued their financial support even after my graduation. Consequently, I was disappointed with the emerging situation. I used to think that my degree is useless to earn and support my family. Therefore, I started applying to universities in the UK for further study.

It was the month of January 2009, I started preparing the International English Language Testing System (IELTS) to qualify for admission. The English language test was mandatory to enroll in a foreign university as English is the means of communication. Then, I also prepared to manage the tuition fees for the master's degree in the International Management Program (IMP) which needed a big deal of money around $\$ 10,000$. It was not an easy task for me to invest in education in the UK because I belong to the middle-class family from the eastern part of Nepal. My parents has a traditional farming profession but, they fully supported me for my higher education trip to abroad. They always encouraged me to go abroad for my higher education. When I succeeded to get admission into one of the UK's Universities, they paid the entire tuition fees and travel expenses as well. After I went to the UK, I managed to have a parttime job to support my study and accommodation. I used to work full time during public holidays and summer holidays. I achieved a quality education and earned good money during my stay. Besides, I became financially successful to support my family.

Hence, as long as the abroad study is concerned, for me, it is the migration process that has been developed from the necessity for survival to the necessity for a better life (Neamtu, 2011). After the completion of my study in 2012, I got an opportunity to work in a full-time job 
in my post-study-work visa. During that time, I earned some money along with the managerial job experiences.

During my student visa period, I also saw the plight and difficulty of the immigrant students in the UK due to the negligence of the educational consultancies in Nepal. I observed the misfortune of young students in foreign lands. Therefore, I was encouraged to start an education consultancy to provide quality services in the field of international education. Coincidently, after my return, I joined MPhil at Kathmandu University for my further study. During the research, the issues of student migration always remained my area of interest. In this regard, I was inspired to explore the particular issues on the youth trend of abroad study as my dissertation topic.

So far, I have sent many students who have passed their higher secondary levels all over the world such as the United States, the UK, Australia, Canada, and many other countries for higher education. Talking to their parents, I have found that even the parents are ready to pay the high tuition fees in international universities as they believe that their children can earn a quality education and later support them financially. In the same way, Wagle (2010) also defended that the parents are ready to pay and send their children abroad regardless of their low economic status. Likewise, students also believe that they not only achieve quality education but also find a better lifestyle. Consequently, students leave their country for their academic purpose and gradually settle down after the completion of their study. In this sense, the youth culture of studying abroad shows that student migration has become a global phenomenon, particularly in developing countries.

\section{STUDENT MIGRATION: CONCEPT AND CONTEXT OF NEPAL}

Student migrations seek growing attention in both origin and destination countries. The destination countries gain income on the one hand, and the other hand, leaving countries losses their intellectual wealth (Jong \& Fonseca, 2020; World Bank [WB], 2006) due to the increasing trend of student migrations. It benefits the developed countries and suffocates the developing countries like Nepal in terms of economic growth. In the context of developing countries, there is an increasing number of students who leave the country to pursue their higher education abroad (Ghimire, 2019; Sokout et al., 2020). The trend of leaving the origin of the country is widely crossed towards all over the world, mostly in Australia, the UK, the United States of America (USA), and Canada.

It is indeed true that international student mobility is an important channel through which high-skilled immigrants arrive (Suter \& Jandl, 2006). Thus, the flows of abroad going students are still unexplored as both the quality of higher education and the earning levels are considered key issues (Brezis \& Soueri, 2011). The opportunities for getting the qualities of life and education may encourage them to motivate international students to fly abroad (United Nations Development Programs [UNDP], 2009). Likewise, the increasing demand for the quality 
higher education of the international degree has become the central point in attracting international students abroad (Chacko, 2020). However, Costello (2015) noted that student migration is an academic experience where students physically leave their home countries to engage in college study, cultural interaction, and move in the host country. Thus, thousands of international students have been going abroad for their higher education. They spend millions of dollars on their tuition fees in international institutions (Raghuram et al., 2020).

They even move out of their country to study and most of them settle down in the host countries after completing their study (Tu \& Nehring, 2020). Student migration is broadly taken as a crucial investment to secure the future of students from developing countries like Nepal. In the same way, student migration is defined as a life period filled with fantasy, excitement, romanticism, and a different mix of cultures of human (Tjaden, 2018). They leave their home countries with the hope of getting skills, knowledge, and other valuable resources that can be useful to them after returning their home country. Likewise, they have an opportunity to explore themselves after the completion of their study. They can garner international work experiences as well as earn money during their stay abroad (Tran et al., 2020). Hence, student migration has become the prime concern of both economic and social development because of its quality education and recognized degree. Finally, it can be observed that student migration takes place when the person moves between the countries either temporally or permanently, for education and employment (Goldin \& Reinert, 2007) or escape from the adverse political environment of their countries. As long as the abroad going students are concerned, the number of abroad going Nepalese students are increasing day by day from Nepal to foreign lands. Similarly, some of the key reasons for leaving the home country could be for quality education, better lifestyle, language learning process, maintain status in society, job opportunities and financial reasons (Abdullaeva, 2020), and so on.

Moreover, flying abroad of youth talents from developing countries to developed countries has brought the situation of brain drain in developing countries like Nepal (Brooks \& Waters, 2011). Thus, it may bring the tough situations to our country since the young talents are fleeing to the developed countries. In contrast, some of the students do not want to come back to home countries from abroad. In the context of abroad study, Ghimire (2016) calculated that the number of abroad going is higher by around 7 percent compared to fiscal 2013-14 when 28,126 students had got the certificate. The number of No Objection Letter (NOC) seekers, now has been tripled. This shows that the dangerous trend of leaving countries for educational purposes has been increasing since recent years. Furthermore, Khania (2007) states that every year almost $25 \%$ of students leave Nepal for higher education. Hence, he stressed bringing them back who go to the USA, Australia, UK, Canada, Denmark, Malaysia, and many more. Once they come back to their home country; they are more inclined to go abroad (Smith, 2006). This information states that the rising trend of student migration has become a crucial issue in the context of Nepal. 
Afterward, it is vital to explore the reasons for motivation, and excitement among prospective students to fly abroad for their higher education, even though there are several universities and colleges in the home country itself. On these premises, several questions were playing in our mind as researchers like; How do the students gain such immense excitement to o go abroad for further studies? Why are they motivated to fly abroad to study in the foreign universities? How do the international students experience the socio-cultural challenges while flying abroad to pursue their higher education? How do they prepare themselves for an abroad study in developed countries? Despite the prospect of exploring a number of questions relating to the stories of international migrant students, the study is focused only on uncovering the excitements, motivations and aspirations while flying abroad to pursue higher education in developed countries. Concerning these questions, we only address few which are: How students were motivated to fulfill their higher education dream abroad? How do the students narrate the stories of their excitement towards study abroad? From these above questions, we have determined the crucial question which needs to be addressed is "How do the Nepali students narrate their motivation, and excitements while flying abroad to pursuing higher education in the developed countries?" as issues of this study.

\section{LITERATURE REVIEW}

\section{Reflection on the Trend of Student Migration}

Global interconnectedness is rapidly increasing now, thus, student migration takes place from one country to another country mainly (Masud, 2020) through the information which is provided by the peer and the network of migrant people in abroad (Davis et al., 2002). Concerning it, Sharma (2009) states that student migration is caused due to the lack of further educational opportunities, peer influences from the previous migration history of the family, and the economic cause in the developing countries. Similarly, most of the programs involve experiential education that focuses the effective learning activities, pragmatic education, and new language learning with a diverse cultural environment (Pechak \& Thompson, 2009). They found information about the job opportunities, high qualities of accommodation, and other facilities are supplied by the kinds of students who have already been resided in the foreign land, and are likely to attract the students from developing countries. In the same way, some of these dimensions such as opportunities for career perspectives, self-development, and personal growth, socialization, and leisure, cross-cultural interest broadly attracted students to higher education abroad (Aresia et al., 2018). Moreover, Levie (2007) even revealed that the high rate of unemployment of the university graduates in the home country and the unstable political situation could be the major push factors to migrate student to the developed countries from the developing countries. Conversely, studies even illustrated that some privately funded universities run the foreign degree courses for which they need to pay a high amount of money for the quality of education. However, due to the lack of job opportunities in the origin country, 
they may be less likely to pursue their education in the home country, and get instigated to move abroad. In the same way, Sharma (2015) stated that Nepalese students are frustrated with the traditional types of education systems, lack of job opportunities, and political instability in Nepal. Thus, they are pushed to fly abroad for their education at first and gradually involve in entrepreneurship and jobs.

In general, student migration was reported to be concerned with quality education, prosperous life, stereotypical ideology, financial support, self-dependent, etc. Nevertheless, there can be many other reasons subjectively independent to an individual which carry pertinence to be explored.

\section{Motivation towards Student Migration}

The foreign universities, as literatures report, establish a highly internationalized university system which turns them as a top destination university for international higher education. This is agreed by Lee (2014) who mentions that the higher educational institutions abroad motivate students, not only through the quality degree programs but also for the economic opportunities. Similarly, these universities are even applauded for maintaining quality of education among students when they attain the provided class and subjects (Brooks, 2018) And while talking about the motivations to go abroad, Varun and Okkonen (2012) stated that motivations are not only vital issues to gain the objectives and goals of the students but also to share the knowledge in the groups. Hüfner (2003), in the similar context noted that higher education is an intellectual place where students construct or gain knowledge that can meet their as well as parents' expectations, find the industrial relations, extend collaboration, and the networking with each other.

Although there are lots of higher education institutions including public and private universities, the number of student migration is currently increasing in the country. The probable reasons behind this could be the international competitiveness, underpinning of initiatives outlined in the policy texts, and the desire to involve completely in an international higher education market (Slaughter \& Cantwell, 2012). In the similar context, Parajuli and Wagley (2010) has discussed the lack of effectiveness in management of higher education in Nepal which can be an obstacle to its competitive image among students. Thus, students exhibit readiness to pay premium fees for acquiring their degrees, up to three times the amount charged to local students for the top host countries like the USA and the UK (Lall, 2008). The aforementioned articulations make it clear that despite the expensive charges, students from developing countries like Nepal are attracted to foreign degrees.

Apart from the instigators in the home land, recognition of higher education as a real part of globalization (Qiang, 2003) can be another possible contributor to the outflow of students to developed countries. Likewise, Aguinis et al. (2013) noted that economic rewards can also be a significant factor to motivate students as they will have a part-time employee available along with their studies. Besides, the means of communication has also been the key 
issue in receiving higher education in abroad. Many youths are found to have been attracted to foreign countries due to the socialization of the international language which has value in the labor market in the world (Varghese, 2007). In fact, it is widely appreciated that higher education may increase employment opportunities where they can involve an international dimension which may entail travel, working in another country, understanding other cultures and languages (King \& Ruiz-Gelices, 2003). Apart from these, as Nyaupane et al. (2010) stated, the most important motivations for foreign students are influenced by both the internal (personal traits, financial situations, and social norms) and external characteristics (culture, language, and people). Migration of students from developing countries due to the above stated reasons has ultimately led to the arrival of high-skilled immigrants in the developed countries (Suter \& Jandl, 2006), while the out flux is even complained to be probable of jeopardizing the socio- economic development of the country of origin. However, how these motivations work as contextual phenomenon has still not been explored to its fullest. And since the study tends to narrate the experiences of student migrants from different socio- cultural contexts, it can be a contribution to revealing the contextual challenges to retention of the youths in the homeland.

\section{Student Mobility and their Excitements}

In general, student mobility is concerned with quality education, prosperous life, stereotypical ideology, financial support, self-dependent, etc. or there could be many reasons independent to an individual. While exploring how the students of Nepal get instigated to move abroad, Sharma (2015) stated that Nepalese students are frustrated with the traditional types of education systems, lack of job opportunities, and political instability in Nepal. There are a lot of public and private funded higher institutions in Nepal. Several universities like Tribhuvan University (TU), Kathmandu University (KU), and Purbanchal University (PU) along with the more than 1000 affiliated campuses (Ministry of Education, Science and Technology hold a regular enrolment of about 382,000 students in Nepal ([MOEST], 2017). These institutions, though, are supposed to align to the aim of improving the competitive skill manpower, to develop the knowledge through effective research skills; these achievements still lack in the higher education graduates in Nepal (MOE, 2010). While there is always debate on the quality of education provided by these institutions in the country, it is believed that the quality of life and the recognized degree are gained in developed countries. It is even replicated as a truism that they are pushed to fly abroad for their education at first and gradually involve in entrepreneurship and jobs. At this, it can be considered crucial to uncover how the students, who are studying in the homeland discover the underlying opportunities in the foreign countries which induce their mobility as international students.

\section{PURPOSE AND RESEARCH QUESTIONS OF THE STUDY}

The purpose of this research is to explore the motivation and excitement of student migrants who want to leave the country for the educational purpose from developing countries to the 
developed countries. For achieving these purposes, the study has been guided by the following research questions:

1. How do the students articulate being motivated to fulfill their higher education dream abroad?

2. How do the students narrate the stories of their excitement towards study abroad?

\section{METHODOLOGY}

\section{Research Design}

The study has been made, resting on the socio-constructivist paradigm which considers the construction of knowledge through experience and reflection upon the same (Honebein, 1996). Believing that reality about student migration and their situation is multiple and subjective (Castellan,2010), we attempted exploring the reality about motivation and excitement for abroad study by assembling participant's views, their background, and experiences (Creswell, 2003). For this, narrative inquiry was used as research method which was helpful in assembling the stories (Khalina et al., 2018) of student mobility and the challenges they experienced in the educational and employment aspirations in Nepal.

\section{Participants}

The participants in this study were selected from among the students who sought educational consulting services in Kathmandu, Nepal. Three participants (Resham, Bina, and Rojina) were selected through purposive sampling because they possessed strong sense of motivation, and excitement towards abroad study. These participants represent typical cases of educational migration among Nepalese youths in terms of age, marital status, educational qualifications, and locale. Stories of these participants are narrated, giving pseudo names to them so that the ethical consideration of anonymity could be maintained. Their profiles, with pseudonyms appear in Table 1:

Table 1. Participant Profile

\begin{tabular}{lccccc}
\hline Pseudonym & Gender & Age & $\begin{array}{c}\text { Marital } \\
\text { Status }\end{array}$ & $\begin{array}{c}\text { Educational } \\
\text { qualification }\end{array}$ & locale \\
\hline Resham & Male & 20 & Unmarried & 10 plus 2 & Urban \\
Bina & Female & 22 & Married & Diploma Nursing & Urban \\
Rojina & Female & 20 & Unmarried & Bachelor degree & Rural \\
\hline
\end{tabular}

\section{Participant 1: Resham}

Resham originally belongs to Bhaktapur district who always dreams to fly to the USA for further study. Once he completed his School Leaving Certificate (SLC) securing distinction marks (83\%), he started dreaming of going to the USA. Hence, he wants to pursue his education in the USA as 
it is his dream-land as well as his destination, from where he wants to support his family in Nepal.

\section{Participant 2: Bina}

Bina comes from Butwal and she wants to go to Australia for her higher education. She is married and wants to take her husband as a dependent. For this purpose, she made her third attempt to take the IELTS examination. She is supposed to score 7.0 in each skill test of IELTS, but so far, she has only scored 6.5 as the highest on her $3^{\text {rd }}$ attempt. She is quite obsessed with her journey to Australia.

\section{Participant 3: Rojina}

Rojina, coming from the eastern part of Nepal, grew up and completed her study in India from where she prepared her academic journey for the UK. She completed her School Leaving Certificate and higher education from Darjeeling, India. Because her father was an army in India, she spent most of her childhood in different cities of India. She aspired to pursue higher education in the United Kingdom.

Engagement in the Field and Data Collection

After obtaining ethical approval from the university to which the researcher belonged, informed consent of the research participants was taken. We personally visited them and engaged with them for a prolonged period of time. In depth interview was used as method to assemble the participants' behavior, interest, and actions (Stake, 2005). For collecting their experiences as narratives, each participant was interviewed 2-3 times across a period of three months.

\section{Data Analysis Procedure}

Data collected from the participants of this study was transcribed in the same order it was conducted (Peräkylä, 1997). The transcribed data was further coded, taking references from the interview transcripts, participants' observation, field notes, journals documents, literature, artifacts, photographs (Saldana, 2009). While doing so, we adopted three strategies of rethinking, reorganizing, and reflecting on the interim text of the research from our positions. Rethinking their stories from our position helped us to present their narratives in the third person because we have more flexibility in presenting the characteristics of our participants. In order to present several fragmented events in the life of the participants, we made a plot of the stories and employed our reflection to generate meaning. Usually, we have employed thinking narrative techniques of Saldana (2014) for generating themes from their interview. We generated two themes which further consists each three stories. The first theme is "Motivation towards the flying abroad for higher education" and incorporated stories" Resham's American dream: Motivation for pursing higher study and socio-economic prosperity", "Friends stories motivated Bina to explore Australia", and "Rojina's motivation: Discover the world". Similarly, the second theme "Excitement for abroad student mobility" and it includes stories as "Wings of Resham's flying: Excitement for abroad student mobility", "Bina's excitement to explore 
Australia", and "Rojina's excitement to fly to the UK" respectively. These themes reflected the student's motivation, and excitement for their abroad study. Insights were later developed through analysis, for which literature review was used for legitimizing the developed understanding.

\section{RESULTS AND DISCUSSION}

\section{Motivation Towards the Flying Abroad for Higher Education}

\section{Resham's American Dream: Motivation for Pursing Higher Study and Socio-economic Prosperity}

Most of the students from the developing countries are motivated and excited to pursue both for their higher education and the socio-economic developments towards the international University (Turcan \& Pirgaru, 2019). Resham could be no exception to achieve such a dream. Resham's motivations to go abroad for higher education and wondered what appealed him to leave his country. He said,

"During my college time, I always dreamt of going to the United States. Most of my friends and relatives have already settled down in the USA. They also encourage me to go there. In addition; the USA degree is recognized and provides more opportunities after our further education in comparison to the other countries."

Resham's narration reminded us of our high school days when we used to discuss of the dream of going abroad at any cost. His words even reflected his desperation for the Ameriacan dream, which, as mentioned by Bensefia (2015). It is about the liberty, unlimited opportunities, simple living, happy family, and supporting oneself with honest, hard work where no one vies for things like that anymore.

The way Resham narrated his story revealed his anticipation that the USA would bring lots of opportunities for him if he completed his studies there. He perceived that foreign study would teach him to appreciate different cultures and languages which he illustrated as follows:

"I see my career and education in America. I even tried my best to score higher marks in the language proficiency test. My parents are also supporting me financially for the processing costs. If I score higher points in SAT and TOEFL, I will also able to find a scholarship at the university."

In a nutshell, he narrated the career opportunities and educational prospect as his motivation to go to the United States. The same motivation, as he narrated, has encouraged him to join the English language classes which he considered to be needed for getting enrolment in the international universities.

\section{Friends Stories Motivated Bina to Explore Australia}

Bina was motivated by the stories of her friends who had been working in Australia for a year. She said, "As far as I know, Australia is the best destination for international students due to its recognized degree and job opportunities." Most of them have earned handsome money along 
with their study. They were studying as well as working in a hospital in Australia and they shared that they had a very good life there. They even supported their families financially from Australia. They are financially able to help their younger siblings' education in Nepal with the earning they made in Australia. They were hopeful to get Australian citizenship after they completed their education. Similarly, globally ranking universities has also motivated to explore meaningful international experiences for their future carrier (Marklein, 2017). Therefore, she is motivated to go to Australia to pursue her nursing study and for her better future. She said, "I am influenced by my friends in Australia who have been studying and working for a long period. They are earing better than in other countries.

She always thinks of being self-dependent in her life. Hence, she is hopeful to start her better carrier in Australia with a recognized degree. Therefore, she figured out that if she could complete these courses in the Australia, it would equip herself with the lifelong learning skills and experiences to run her own professional. She thought that studying abroad would be inspiring, motivating, and life-changing since the opportunity to study abroad might occur only once or twice in her life. She also expected to find out about her chosen course that would explore different ideas. Further, it would help her to earn some amount for her secure life in future. Bina, added that education in Australia would give her both the self-dependent and improve her professional carrier. She is an optimistic that abroad degree would bring her a completely different perspective to explore news ideas into her learning skills. She moreover expected that there would be an assignment and practical workshop where she would be required to do some business networking with other people within the industry. She would find some amazing information and practical skills which might lead her to grow her as practical women in the society.

\section{Rojina's Motivation: Discovering the World}

After completing her higher secondary, Rojina planned to study in the UK, where she hoped to start her new life because of having quality education and the economic opportunities in the UK. She was excited to be the student who wants to leave her country or territory of origin and move to another for study (Prazeres, 2019). She shared, "I hoped that it would be easy to get a part-time job and would have a better life than I had." She also dreamt of her ordinary student life journey from the developing country to the world's top education provider destination in the UK. It is indeed true that the internationalization of higher education has been growing significantly worldwide. She further shared, "although I was born and studied in India, I was always motivated to pursue a higher degree in the UK for the quality education." After completing her higher secondary, she planned to study in the UK in comparison to other countries. as most of her relatives were living there.

Like Rojina, as Bhati and Anderson (2012) mentions, foreign students are aspired to go abroad which will bring better opportunities and challenges in an increasingly globalized and interdependent world. Driven by the same motivation, Rojina thought to move to Kathmandu as there were mushrooming numbers of educational consultancies. Even the UK immigration 
rule was also made comparatively easier for international students at that time. But, in Nepal, she would only pass his time doing hardly anything besides her studies. She is extremely motivated to go abroad and settle down thereafter his higher education due to the quality and recognized degree. Aligning to Philips (2018), her motivation was her dream of navigating a world that becomes simultaneously more interconnected and less capable of silencing longstanding inequities.

\section{Excitement for Abroad Student Mobility}

\section{Wings of Resham's Flying: Excitement for Abroad Student Mobility}

Resham, is excited to fly abroad to improve his person in his future with the education he gains from the USA. Generally, it is safe to say that youth can contribute to building a better nation if they get a quality education. Thus, it creates opportunities to interact with different people from around the world that enables him to understand abroad. In this sense, he is willing to be a permanent resident of the United States. In the same context, Cuss (2012) noted that personal development, the fulfillment of expectation, the impact of the US, travel, and connections to the new culture are key issues to encourage the youth for their higher education abroad. Foreign universities attract the best students from all over the world through scholarships and offer generous stipends to some international students (Foster \& Varghese, 2009). Thus, the possibility of quality and practical education of overseas has added to Resham's excitement to get the job in an international market.

Studies have said that youths like Resham, can move abroad for a plethora of reasons such as higher education, in search of job opportunities, and permanent settlement (United Nations International Children's Emergency Fund [UNICEF], 2014). It also can be heard in the story of Resham that studying abroad is for quality education to grasp better opportunities in the upcoming future. Resham's excitement towards study abroad indicated that excitement for his passion, interests, and capabilities are the keys to motivate him to study abroad. As Campbell (2011) stated, studying abroad is an exciting opportunity because it promotes the inter-cultural relationship between international students and native students. Resham's story also revealed that he has desired to go to the USA to broaden his horizon of knowledge into international standards. To recapitulate, he seemed to be representing the voices of youths that abroad education can develop the knowledge and skills students need for professional, technical, and managerial skills (Brint \& Clotfelter, 2016). Hence, they are excited to fly abroad for their higher education.

\section{Bina's Excitement to Explore Australia}

As far as the story of Bina KC is concerned, she was excited to make her decision of applying to a university Australia for her further education. She said that she would be completely a home bird in Australia. She would love being near her family, friends, and hometown. She also imagined that being away from home would make her sad because she would travel thousands of miles away to start afresh meeting with new people and new cultures. She said, "I was excited 
to pursue my further education in Australia as most of my friends are going to Australia with their dependent." She further mentioned, "I had also participated in the seminars and programs which had also helped me to go to Australia." Due to the low quality of education and fewer opportunities in Nepal, most of our participants have planned to fly to Australia.

Bina was found to be incredibly excited about her journey to Australia. Until she applied for a student visa, she would constantly be questioning whether it would the right thing to do or whether she would be pushing herself too much. However, many of her friends had encouraged her to apply for Australia since she decided that it was a chance of her lifetime. She knew that she needed to do research and speak in mass about her plans to Australia. Therefore, she had participated in several seminars in Nepal by universities' representatives.

Furthermore, she would feel better if she had some relatives or friends in Australia. She imagined that it would be an incredibly great time if she would meet them. In this story, of Bina $K C$, several challenges in her study, families, and her future abroad were also expressed beside her attraction to modern technology in Australia. Her attraction signposted that development of local youth sense is increasingly influenced by global electronic media such as television programs in dialogue with local managers, seminars of event organizers, sponsors, and various entertainment venues (Gjelstad, 2014). Bina has garnered lots of experiences about abroad study through the connection of the different channels such as television, Facebook, the internet, and so on. Hence, she narrated her excitement about collecting different information about abroad by using modern technology and the seminars, events on the abroad study, simultaneous to her dream of becoming a self- dependent person.

\section{Rojina's Excitement to fly to the UK}

Rojina is excited to start her journey to the UK to pursue her higher education. She wishes she will get admission and visa to the UK; she will become self-dependent and a determined lady after completing her education from abroad. Rojina shared, "I am thinking that abroad study can bring confidence and self-dependent to their life." She is confident to be strong and selfdependent. Although she would be traveling thousands of miles away for her higher study, she was hoping to start her new career in the UK. She hopes that the journey to the UK would bring changes in her life. She was an optimistic to become an academic as well as the financial sound. She had also seen some relatives who already had gone and settled down there. I also had supported the idea that international education as a means to improve better opportunities for her advanced carrier, personal growth, and life skill development (Rennick, 2015). It was also found from her story that she spent a huge sum of money to improve her English. She was hoping to get opportunities to meet new people and share their culture to adjust to the developed countries. She further shared,

"I will achieve an international degree certificate which is globally recognized. I will also gain valuable work experience which will enrich my professional lifestyle for my future. I will able to become self-dependent due to an international degree. I will have my own identity here in Nepal." 
Her story illustrates the hope for the successful life journey and experiences of the students and their study and work life in the UK. In doing so, highly talented immigrants from the developing countries to the developed countries are attracted towards the economic opportunities and quality of education which may cause the brain drain in the developing countries (Brooks \& Waters, 2011). Increasing demand for the quality higher education of international degrees has become a central point in attracting international students. Therefore, thousands of Nepalese students are going abroad every year for the sake of such an international degree.

\section{CONCLUSION}

This research paper has explored the motivation and excitements among students considering abroad mobility, which has been widely occurred all over the world, mostly in Australia, the UK, the USA, and Canada. There are several reasons to motivate them to fly abroad. The qualities of higher education and economic prosperity have become a key issue in increasing international students. Thus, student migration has become the most contributing concern for the economic and social development of the country due to its quality education and its recognized degree. Similarly, they also understood the values of foreign degrees and the existing political instabilities are the main push factors to motivate students abroad. These outlooks of abroad study are one of the reasons for excitement among students regarding their study. However, within this excitement, they tackle a lot of socio-economic challenges and language barriers to fly abroad for achieving their bright future.

\section{IMPLICATIONS OF THIS STUDY}

Based on the finding of this article, this study implies ideas and steps to secure the situations of growing numbers of international students, higher education institutions, and educational policymakers of both origin and destination countries. It has also explored the experiences and the practical knowledge of the required prerequisites during the process of study abroad. Thus, the youth will be concerned about the practices and rules which are needed to be done before the journey of their study abroad. Similarly, educational policymakers can also interact with the ministry of education to understand the current problems of the prospective students of the country to support the abroad education of the youth. Hence, they can provide effective education and become the hub for the education of international students. In the same way, this paper has also provided the best possible solution to the abroad going process, their struggle, and the process of student visa of the prospective students. Therefore, this paper is vital to develop a country's education and the economic situation in the coming future. Besides it, this paper becomes a proper guideline to study the student migration for the future researcher. 


\section{REFERENCES}

Abdullaeva, N. (2020). Terminological and theoretical considerations of international student migration. In: Tertiary student migration from Central Asia to Germany (pp. 19-38). Springer VS. https://doi.org/10.1007/978-3-658-29020-7_2

Aresia, G., Alfieria, S., Lanza, M., Martaa, E., \& Moore. S. (2018). Development and validation of a multidimensional motivations to study abroad scale (MMSAS) among European credit mobility students. International Journal of Intercultural Relations, 63(2018), 128-134.

Bensefia, M. M. A. (2015). The ambiguity of the American dream and the shift to Hollywood dream. (Doctor of Philosophy dissertation, Abou Bakr Belkaild University). http://dspace.univ-tlemcen.dz/bitstream/112/8031/1/amine-bensefia.pdf

Bhati, A., \& Anderson, R. (2012). Factors influencing Indian student's choice of overseas study destination. Procedia-Social and Behavioral Sciences, 46(2012), 1706-1713.

Brezis, E. S., \& Soueri, A. (2011). Why do students migrate? Where do they migrate to? (Almalaurea working papers no. 25). http://www2.almalaurea.it/universita/pubblicazioni/wp/pdf/wp25.pdf

Brint, S., \& Clotfelter, C. T. (2016). US higher education effectiveness, The Russell Sage Foundation Journal of the Social Science, 2(2), 2-37.

Brooks, R. (2018). Higher education mobilities: A cross-national European comparison. Guildford: University of Surrey. https://doi.org/10.1016/j.geoforum.2018.05.009

Brooks, R., \& Waters, J. (2011). Student mobility's, migration and the internationalization of higher education. Palgrave Macmillan. https://doi.org/10.1057/9780230305588

Campbell, N. (2011). Promoting intercultural contact on campus: A project to connect and engage international and host students. Journal of Studies in International Education, 16(3), 205-227.

Castellan, C. M. (2010). Quantative and qualitative research: A view for clarity. International Journal of Education, 2(2), 1-14.

Chacko, E. (2020). Emerging precarity among international students in Singapore: Experiences, Understandings and responses. Journal of Ethnics and Migration Studies, 1-17. https://doi.org/10.1080/1369183X.2020.1732618

Costello, J. (2015). Students' stories of studying abroad: Reflections upon return. Journal of International Students, 5(1), 50-59.

Creswell, J.W. (2003). Research design: Qualitative, quantitative and mixed methods approach (2nd ed.). Sage Publication.

Davis, B., Stecklov, G., \& Winters, P. (2002). Domestic and international migration from rural Mexico: Disaggregating the effects of network structure \& composition. Population Studies, 56(3), 291-309. 
Foster, S. G., \& Varghese, M. M. (2009). The making of the Australian national university. ANU E Press.

Ghimire, B. (2016). Flying abroad for international degrees continues to soar. The Kathmandu Post. http://kathmandupost.ekantipur.com/news/2016-12-29/greener-pastures.html

Ghimire, B. (2019). As study abroad numbers rise, Nepali students land in trouble. University World News: The Global Window of Higher Education. https://www.universityworldnews.com/post.php?story=20190301101826555

Gjelstad, L. (2014). Worlds of sparking lights: Popular music and youth cultures in Solo, Central Java. In R. Hoefte \& H. S. Nordholt (Eds.), SONIC Modernity in the Malay World (pp. 219248).

Goldin, I., \& Reinert, K. (2007). Globalization for development: Trade, finance, aid, migration, and policy. World Bank and Palgrave Macmillan. http://hdl.handle.net/10986/6618

Golley, J., \& Kong, S. T. (2012). Climbing the intergenerational ladder of education in urban, migrant and rural China. In H. McKay \& L. Song (Eds.), Rebalancing and Sustaining Growth in China (pp. 225-250).

Honebein, P. C. (1996). Seven goals for the design of constructivist learning environments. In B. G. Wilson \& D. N. Perkins (Ed.), Constructivist Learning Environments: Case Studies in Industrial Design. Englewood Cliffs.

Hüfner, K. (2003). Higher education as a public good: Means and forms of provision. Higher Education in Europe, 28(3), 339-348.

Khalina, N. V., Kovaleva, A. V., Voronin, M. S., Anikin, D. V., Valyulina, E. V. (2018). Asian educational discourse: Construction of ontological security. Journal of Social Studies Education Research, 9(1), 11-27.

King, R., \& Ruiz-Gelices, E. (2003). International student migration and the European 'year abroad': Effects on European identity and subsequent migration behavior. International Journal of Population Geography, 9(3), 229-252. https://doi.org/10.1002/ijpg.280

Lall, M. (2008). Educate to hate: The use of education in the creation of antagonistic national identities in India and Pakistan. Compare: A Journal of Comparative and International Education, 38(1), 103-119. https://doi.org/10.1080/03057920701467834

Levie, C. (2007). Education and migration. http://www.siterouces.worldbank.org/INTMENA/resources/EDU_08-CHAP08education.

Masud, M. M. H. (2020). International migration and polymedia: The use of communication media by Bangladeshi students in Germany. Research in Social Science and Technology, 5(3), 95-110. https://doi.org/10.46303/ressat.05.03.5

Ministry of Education, Science and Technology. (2017). Education in figures 2017 (at a glance). https://moe.gov.np/assets/uploads/files/Education_in_Figures_2017.pdf 
Parajuli, M. N., \& Wagley, M. P. (2010). Comparative education and development: Reflections from Nepal. Compare: A Journal of Comparative and International Education, 40(6), 835840. https://doi.org/10.1080/03057925.2010.523262

Pechak, C. M., \& Thompson, M. (2009). A conceptual model of optimal international servicelearning and its application to global health initiatives in rehabilitation. Physical Therapy, 89(11), 1192-1204. http://dx.doi.org/10.2522/ptj.20080378.

Peräkylä, A. (1997). Validity and reliability in research based tapes and transcripts. In D. Silverman (Ed.), Qualitative Analysis: Issues of Theory and Method (pp. 201-220). London: Sage.

Peterson, C., Engle, L., Kenney, L., Kreutzer, K., Nolting, W., \& Ogden, A. (2007). Defining terms for use in designing outcomes assessment projects. In M. C. Bolen (Ed.), A Guide to Outcomes Assessment in Education Abroad (pp. 163-203). A gathon Press.

Philips, J. (2018). A global generation? Youth studies in a postcolonial world. Societies, 8(1), 118. https://doi.org/10.3390/soc8010014

Qiang, Z. (2003). Internationalization of higher education: Towards a conceptual framework. Policy Futures in Education, 1(2), 248-270. https://doi.org/10.2304\%2Fpfie.2003.1.2.5

Raghuram, P., Breines, M. R., \& Gunter, A. (2020). Beyond \#fees must fall: International students, fees and everyday agency in the era of decolonisation. Geoforum, 109 (February 2020), 95-105. https://doi.org/10.1016/j.geoforum.2020.01.002

Rennick, J. B. (2015). Learning that makes a difference: Pedagogy and practice for learning abroad. Teaching and Learning Inquiry, 3(2), 71-88.

Sharma, C. H. (2009). A study on the causes of educational migration in Nepal. Unpublished Master of Philosophy thesis on education, Kathmandu University School of Education.

Sharma, N. (2015). More student seeking "no objection" to study abroad. My Republica. http://admin.myrepublica.com/society/story/23904/more-student-seeking-noobjection-to-study-abroad.html

Sokout, H., Ramaki, N. M., \& Usagawa, T. (2020). Prospects of learning analytics for higher education in developing countries: A case of Kabul polytechnic university, Afghanistan. The Institute of Electronics, Information and Communication Engineers.

Slaughter, S., \& Cantwell, B., (2012). Transatlantic moves to the market: The United States and the European Union. Higher Education, 63(5), 583-606.

Smith, R. L. (2006). Using human capital theory to develop a policy approach towards college student migration in Illinous. University of Illinous. https://files.eric.ed.gov/fulltext/ED494797.pdf

Stake, R. E. (2005). Case studies. In N. K. Denzin, \& Y. S. Lincoln (Eds.), Handbook of Qualitative Research ( $3^{\text {rd }}$ ed., pp. 443-454). Sage Publications.

Suh, S., \& J. Satcher. (2005). Understanding at-risk Korean American youth. American School Counselor Association: Professional School Counseling, 8(5): 428-35. 
Suter, B., \& Jandl, M. (2006). Comparative study on policies towards foreign graduates: Study on admission and retention policies towards foreign students in industrialized countries. International Centre for Migration Policy Development. http://www.net4you.com/jandlftp/Students_Final.pdf

Tjaden, J. D. (2018). International migration: What data can tell us, and what it can't? Paper presented at the $6^{\text {th }}$ EMN Educational Seminar on Migration "Causes and Consequences of Forced Migration", Bratislava. https://www.emnconference.sk/media/attachments/2018/09/03/day-1-jasper-dagtjaden.pdf

Tran, L. T., Rahimi, M., Tan, G., Dang, X. T., \& Le, N. (2020). Post study work for international graduates in Australia: Opportunity to enhance employability, get a return on investment or secure migration? Globalization, Societies, and Education. https://doi.org/10.1080/14767724.2020.1789449

Tu, M., \& Nehring, D. (2020). Remain, return, or re-migrate? The (im)mobility trajectory of mainland Chinese students after completing their education in the UK. International Migration, 58(3), 43-57. https://doi.org/10.1111/imig.12589

United Nations Development Programs. (2009). Human development report 2009 (Overcoming barriers: Human ability development). http://hdr.undp.org/sites/default/files/reports/269/hdr_2009_en_complete.pdf

Varghese, N. V. (2007). GATS and higher education: The need for regulatory policies. UNESCO.

World Bank. (2006). Global economic prospects: Economic implications of remittances and migration.

http://documents.worldbank.org/curated/en/507301468142196936/pdf/343200GEP0 2006.pdf 